九州大学学術情報リポジトリ

Kyushu University Institutional Repository

\title{
A Field Survey of Traditional Nomadic Dwelling Gers Used as Urban Habitats in Ulaanbaatar, Mongolia
}

Purev, Uelun-Ujin

Interdisciplinary Graduate School of Engineering Science, Kyushu University

Hagishima, Aya

Interdisciplinary Graduate School of Engineering Science, Kyushu University

https://doi.org/10.5109/4055214

出版情報 : Evergreen. 7 (2)，pp.155-171，2020-06. 九州大学グリーンテクノロジー研究教育センター バージョン：

権利関係 : 


\title{
A Field Survey of Traditional Nomadic Dwelling Gers Used as Urban Habitats in Ulaanbaatar, Mongolia
}

\author{
Uelun-Ujin Purev ${ }^{1 *}$, Aya Hagishima ${ }^{1}$ \\ ${ }^{1}$ Interdisciplinary Graduate School of Engineering Science, Kyushu University, Japan \\ *Author to whom correspondence should be addressed: \\ E-mail: ujin@kyudai.jp
}

(Received May 21, 2019; Revised May 27, 2020; accepted Jun 2, 2020).

\begin{abstract}
In Ulaanbaatar, Mongolia, 30\% of households in urban settlements live in traditional mobile dwellings - gers. This study outlines urban gers based on a field survey of 49 households. The authors analyse space heating and thermal characteristics of ger envelopes, which are essential factors for the emission of air pollutants during winters. The results suggest the necessity of urgent policy implementation of the change of coal stoves to other appliances with better energy performance and lower pollutant emissions. Further, there is a need for new, customised methods to improve the thermal insulation of gers, based on local economy and needs.
\end{abstract}

Keywords: Urban informal settlement; ger; traditional dwelling; thermal adaptive behaviour; Ulaanbaatar, Mongolia

\section{Introduction}

Mongolia, located in the northern part of East Asia, has experienced rapid urbanisation since democratisation and the abolishment of the law restricting rural-to-urban migration in 1990. During the 1950s, the urban population of Mongolia was only about $20 \%$ of the total population ${ }^{1)}$. By contrast, the urban share in 2019 was $72.9 \%$, which is higher than the Asian regional average ${ }^{2)}$. Particularly, the population of the Mongolian capital, Ulaanbaatar, increased from about 540,000 in 1989 to about 1,400,000 in 2016, comprising about $46 \%$ of the country's population $^{3)}$. During this rapid urbanisation, rural migrants created unique communities in Ulaanbaatar, known as ger districts, which include many gers as detached houses for urban residents ${ }^{4)}$.

Gers were originally nomadic portable tents made of wooden poles covered with felted wool sheets. The design, structure, and materials of gers reflect the nomadic lifestyle; thus, they are recognised as cultural heritage cultivated throughout the long history of Mongolia's nomadic peoples. Maidar et al. ${ }^{5)}$ provided a historical review of nomadic lifestyle and housing, which is probably the oldest known book written in the Mongolian language. Omoya ${ }^{6)}$ conducted a survey of nomadic gers and reported typical layouts of furniture and living style. Kawagishi et al. ${ }^{7)}$ also conducted a survey of the nomadic lifestyle of 57 nomads residing in the outskirts of Ulaanbaatar in 2006.

On the other hand, many migrants moving from rural areas to Ulaanbaatar in recent decades have been building gers themselves. This affordable type of housing has resulted in the rapid sprawl of unplanned residential districts called ger districts, which have insufficient urban infrastructure for services such as water, sewage, garbage collection, and heating. Fig. 1 shows the expansion of ger districts between 1998 and 2012 ${ }^{9}$. Park et al. ${ }^{9)}$ reported that the area of ger districts increased from $32.15 \mathrm{~km}^{2}$ to $221.15 \mathrm{~km}^{2}$ between 1990 and 2013.

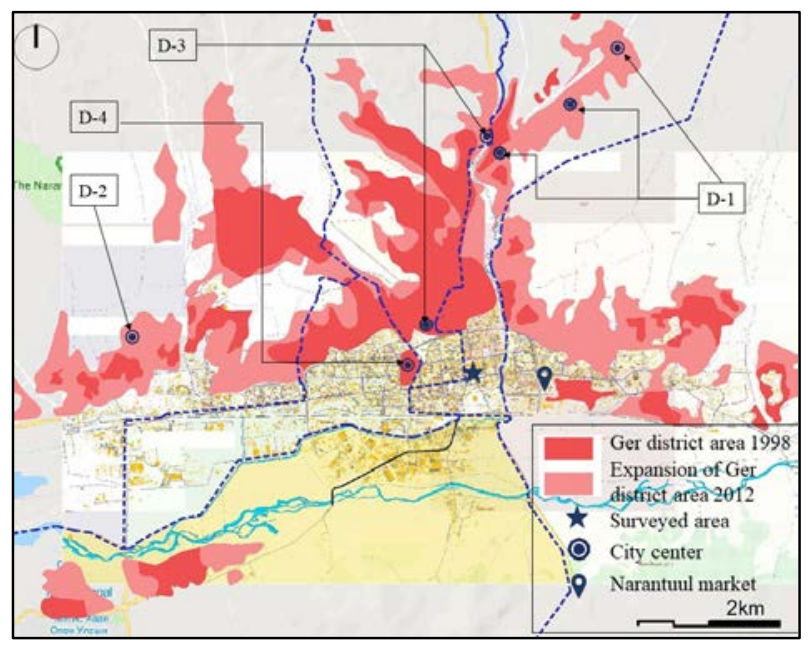

Fig. 1: Map of ger districts, Ulaanbaatar in 1998 and 2012. The location of the surveyed areas is included. From Ochirbat ${ }^{8)}$ modified by the authors.

As past studies such as Yatsuo's ${ }^{10)}$ reported, areas where current ger districts in Ulaanbaatar are located are mostly separated from one another by wooden fences. Enclosures contain one or a few detached houses named baishins and/or gers, as well as a wooden outhouse toilet for one or multiple families. The structure of baishins is 
diverse, made from wooden and brick, and a majority of these houses are self-built or constructed by residents (e.g. Caldieron ${ }^{11)}$ ) as more permanent dwellings compared with gers. Nevertheless, baishins have the same problems as gers, such as a lack of proper connections to urban infrastructures, such as water, sewage, and heating. Yatsuo $^{10)}$ pointed out that the current state of the ger districts can be recognised as a transition from nomadic migration culture to settlement culture in Mongolia.

According to the National Statistical Office of Mongolia ${ }^{3)}$, the share of households living in apartment buildings connected with public infrastructure increased from $32 \%$ in 2010 to $41 \%$ in 2015, most likely because of the government-sponsored low-interest apartment project for low-income households. However, the households living in gers increased from 87,000 to 114,000 during that period because of increased migration; currently, gers are homes to $30.4 \%$ of households in Ulaanbaatar.

Meanwhile, Ulaanbaatar, which has a frigid winter of $40{ }^{\circ} \mathrm{C}^{12)}$ currently suffers from the world's worst air pollution during winter ${ }^{13) 14}$. As Soluyanov et al. ${ }^{15}$ reported, coal-burning stoves used in the houses of the ger districts are responsible for about $80 \%$ of the air pollutant emissions, partly due to the extremely low thermal insulation of gers and baishins.

According to latest data of World Bank 2014 ${ }^{16)} \mathrm{CO}_{2}$ emission per capita of Mongolia was recorded 7.1 Metric Tonnes. As same as most of other developing countries mineral resource is main wealth of Mongolia (Dwiki, 2018) ${ }^{17)}$.

Actually similar difficulties to take countermeasures against environmental issues existed in currently developed societies as Sato et al., 2016 ${ }^{18)}$ reported cases of Kitakyushu, Japan and Emscher, Germany during middle of $20^{\text {th }}$ century (Fujisaki, 2018) ${ }^{19)}$. Nevertheless, developed countries already have strict regulations and implemented advanced technologies to control their local environmental issues as well as global environmental issues, in contrast, developing countries are struggling with lack of technology and economic development (United Nations, 2019) ${ }^{20)}$.

Given these circumstances, in 2013, Ulaanbaatar formulated a master plan for city planning to be achieved by $2030^{21)}$ based on a survey conducted by the Japan International Cooperation Agency (JICA) ${ }^{22)}$. This plan includes redevelopment projects for the integration of fragmented sites in ger districts, temporary relocation of residents of baishins and gers, and the construction of high-rise, well-insulated apartments with proper urban infrastructures, including district heating systems. Enkhjargal and Nishikizawa ${ }^{23)}$ examined the effectiveness of the design process of the project in terms of its prospective environmental and societal contributions. Boldbaatar ${ }^{24)}$ reported that the overall evaluation of the urban redevelopment project was high based on observations and interviews with over 500 people.

Despite such projects, $68 \%$ of all households in Ulaanbaatar currently live in the ger districts; thus, it will take considerable time for the redevelopment of the ger districts throughout the city. Therefore, in addition to long-term urban redevelopment, it is important to take immediate measures such as improving the insulation of houses in the ger districts and replacing current heating appliances with those having higher energy efficiency and emitting lesser pollutants.

In fact, the Mongolian government and the World Bank distributed more than 40,000 fuel-efficient stoves to households in the ger districts with a $50 \%$ to $90 \%$ subsidy for changes with conventional stoves between 2011 and $2015^{25)}$. These improved stoves were designed to place fuel coal beneath wood; thus, they could pass the updraft of the incomplete combustion gases and particle matter through the flame of the burning wood, thereby reducing the emission of air pollutants. In addition, a project to boost the usage of electrical heaters was implemented in 2017 by the Ulaanbaatar City Government ${ }^{26)}$.

Otgonbayar et al. ${ }^{27)}$ evaluated the cost, fuel consumption, and pollutant emissions targeting baishins located in the ger districts under the following three strategies: 1) replacing conventional coal stoves with fuel-efficient coal stoves with low emissions, 2) replacement of coal stoves with heaters that use electricity generated by wind power, and 3) relocation into apartments with appropriate insulation performance from baishins. They pointed out that the first option has the highest cost-benefit performance. On the other hand, Erdenedavaa et al. ${ }^{28)}$ investigated the applicability of the solar thermal system for space heating based on the measurement of a detached house equipped with solar collectors in Ulaanbaatar. Pillarisetti et al. ${ }^{29)}$ monitored the performance of electric heat pumps tailored to cold climate in baishins and gers. Although it is a well-known fact that a frigid climate generally worsens the performance of heat pumps for space heating, their long-term observation in houses where occupants resides as usual shows acceptably moderate performance.

Regarding the thermal performance of houses in the ger districts, Ishikawa et al. ${ }^{30}$ measured room air temperature of 6 gers in Ulaanbaatar in winter and reported that the vertical distribution of room temperature is generally large (up to $20^{\circ} \mathrm{C}$ ), owing to the poor insulation of the ger envelopes. Buyantogtokh et al. ${ }^{31)}$ measured the indoor thermal conditions of 10 gers and estimated the ventilation rates and heat loss coefficients. Tong et al. ${ }^{32)}$ developed a simple numerical tool to estimate the reduction of coal consumption and carbon emission due to insulation aimed at the promotion of insulation retrofitting of baishins in Mongolia.

On the other hand, there have been some questionnaire surveys on residents of the ger districts. For example, Gonchigbat et al. ${ }^{33)}$ conducted a field survey on the satisfaction with current housing of 100 people living in gers located in the urban fringe and the central area of Ulaanbaatar. Caldieron and Miller ${ }^{34)}$ reported that $35 \%$ of respondents in the ger district were satisfied or very satisfied, and 33\% responded that they felt neutral with their current dwellings; however, more than half of them indicated the intention to move to an apartment with suitable facilities.

Considering the fact that coal stoves in ger districts 
account for $58 \%$ of the total emissions in Ulaanbaatar, prompt actions for both the decrease in heating load of buildings and the transition from current coal stoves to heating appliances with low pollutant emissions in the ger districts are strongly needed in order to solve the current air pollution in the short term. In line with that, this study focusses on gers in the ger districts, which are homes to around 114,000 of Ulaanbaatar's urban households according to data reported in 2015³.

Given the knowledge of building environmental engineering, the increase in both the insulation performance of building envelopes and the airtightness is theoretically a simple and well-known measure for decreasing the heating load. In fact, many developed countries have recently promoted high-insulation and airtightness of buildings as countermeasures for climate change, and the building sectors of these countries have gradually reduced the emissions of greenhouse gases per floor area. However, such a simple measure is extremely difficult to widely implement in developing countries, such as Mongolia, owing to the financial constraints of both the government and households. Furthermore, gers were originally temporary tents suitable for nomads to move each season; thus, they have a completely different structure from ordinary permanent buildings. Therefore, the well-known construction methods for high heat insulation and high airtightness cannot be applied to gers. However, there have been few studies that have examined feasible measures for reducing heating load, energy use, and pollutant emissions in gers. Furthermore, the prerequisites for development of feasible measures that match the current ger design, prices of locally available construction materials, lifestyle, income level, and willingness to pay for the housing improvement of ger residents have not been sufficiently determined. Even though interesting field surveys of gers have been conducted in architecture and social science fields, some of them have been reported in neither English nor the Mongolian language; thus, it is difficult for local people and organisations to use them.

Under these circumstances, this study intends to clarify the boundary conditions for establishing applicable measures for the reduction of energy consumption and pollutant emissions as well as to improve the indoor thermal environment. For this purpose, the authors conducted field surveys in Ulaanbaatar. A description of the survey methodologies is presented in Section 2.
Section 3 summarises the observed characteristics of gers, and Section 4 describes household members' behaviours regarding space heating. In Section 5 , the potential countermeasures based on the survey results are discussed. Section 6 concludes the paper.

\section{Outline of field survey}

\subsection{Questionnaire survey on residents of gers}

A questionnaire survey was conducted in August 2018 of 49 gers located in four ger districts in Ulaanbaatar. Household members $(n=67)$ were interviewed about their gers, heating devices, behaviours related to energy use, perception of indoor thermal conditions during winter, and satisfaction with their living conditions.

Before the interviews, 37 questions were developed. The first part comprised questions directed at the household head or responsible members regarding the basic data on the ger and household members. The second part consisted of 21 questions used in separate interviews with each household member on their indoor behaviours and their satisfaction with the ger's thermal conditions in winter. The interviewees were also asked to freely share their opinions, and, based on their statements, the interviewers added questions about related issues, such as the way they defined insulation quality. An entire household interview lasted about 20 minutes depending on the number of household members. The interviews were conducted in Mongolian. For efficiency and accuracy, the interviews were recorded.

Of the 70 individuals living in the 49 gers, 67 interviewees were aged 15 years or older. Photographs of the interiors and exteriors of 43 gers were taken, and the sizes of these gers were measured (with permission) during the interviews using a laser meter. Two household heads agreed to participate but refused to allow the interviewers on the plot, and three household members did not reside in the ger at the time of the interview. These household members were interviewed at their workplaces; interiors of 44 gers were examined.

Table 1 shows the number of gers and household sizes in the sample by area. Ulaanbaatar consists of nine wards: three sub-wards and six pericentral wards. All nine of these wards have ger districts in which the ratio of households living in gers varies between $10 \%$ and $40 \%$, according to a report in 2016 $6^{35}$. The six pericentral wards

Table 1. Number of surveyed households by district and land tenure

\begin{tabular}{|c|c|c|c|c|c|c|}
\hline & District & $\begin{array}{c}\text { Khoroo } \\
\text { (sub-district) }\end{array}$ & Number of gers & $\begin{array}{c}\text { Number of gers } \\
\text { owned }\end{array}$ & $\begin{array}{l}\text { Number of } \\
\text { rented gers }\end{array}$ & $\begin{array}{l}\text { Number of household } \\
\text { members interviewed }\end{array}$ \\
\hline D1 & Sukhbaatar & $\begin{array}{l}\text { 13th, 14th,16th, and } \\
\text { 18th }\end{array}$ & 33 & 22 & 10 & 46 \\
\hline $\mathrm{D} 2$ & Songinokhairkhan & 26th & 7 & 6 & 1 & 11 \\
\hline D3 & Chingeltei & 9th and 19th & 5 & 5 & 0 & 4 \\
\hline D4 & Bayangol & 17 th & 4 & 1 & 3 & 6 \\
\hline \multicolumn{3}{|c|}{ Total } & 49 & 34 & 15 & 67 \\
\hline
\end{tabular}


are the most populous of nine wards in the city; therefore, the survey was conducted in ger districts located in four different pericentral wards. Songino khairkhan has the highest number of households residing in gers $(n=31,338)^{35)}$. The surveyed area in Bayangol is located downtown within $3 \mathrm{~km}$ of City Hall. In contrast, the surveyed areas of Chingeltei and Sukhbaatar are located in a suburban residential zone. The respondents who participated in this survey were not selected in a statistically random manner but rather through a personal connection with the authors (for Bayangol and Sukhbaatar) and by recommendations from the staff of the governor's office at each khoroo (microdistrict) in Bayangol and Sukhbaatar. In addition, the authors visited the gers located in the target area without appointment and requested their cooperation in the survey if occupants had the experience of spending at least one entire winter there.

\subsection{Survey of sales and manufacture of gers}

The authors observed operations of retail businesses selling gers at Naran Tüul Market in Bayanzürkh District, Ulaanbaatar, in August 2018. This huge market is where people could buy gers and replacement parts. The authors visited nine shops in total: three felt sheet shops, three skeletal frame shops, and three shops selling packages with parts for a complete ger. All these shops were managed by manufacturers. In each shop, the authors conducted interviews about the quality, price, and manufacturing products. Furthermore, the authors visited two felt sheet manufacturing plants and observed the fabrication process: one in the 19th khoroolol, Khan-Uul district, and one in Salkhit, Chingeltei district.

\section{Results of interviews with residents of gers}

\subsection{Profile of surveyed gers and households}

Fig. 2 shows the distribution of observed households by size. The statistics of the entire Ulaanbaatar city ${ }^{36)}$ are included for reference. Although target gers and households in this survey were not chosen in a statistically random manner, the present data generally show a similar tendency to the data of the city ${ }^{36)}$, in which four-member households were the most common. Nevertheless, the present data are slightly shifted towards a larger number of household members compared to the statistics. Fig. 3 shows the number of household members employed by household size. This indicates that the mid-sized households tended to have one or two employed household members, and the proportion of those unemployed increased with household size.

Fig. 4 shows the distribution of monthly household income of the sample. The national urban data in 2018 including not only Ulaanbaatar but also other smaller cities $^{37)}$ are also included as references. In the present survey, the mean and median of monthly household income were MNT 600,000 (US\$ 215) and MNT 400,000 (US\$ 140), respectively. In contrast, those for national urban statistics are MNT 1,100,000 and MNT 1,000,000. Considering the fact that the national statistics include data of households living in apartments, the lower incomes the present data identified in gers are adequate might be reasonable.

\subsection{Water and sanitation}

Fig. 5 shows photographs of unpaved streets, a water kiosk, and an outdoor toilet in the observed districts. Because of the lack of infrastructure of water supply and sewerage systems in the ger districts, all surveyed households transport water from water kiosks on foot or by vehicle on unpaved streets to use for daily activities, such as cooking and washing. In water kiosks, water is either delivered by a tanker truck or a kiosk is connected

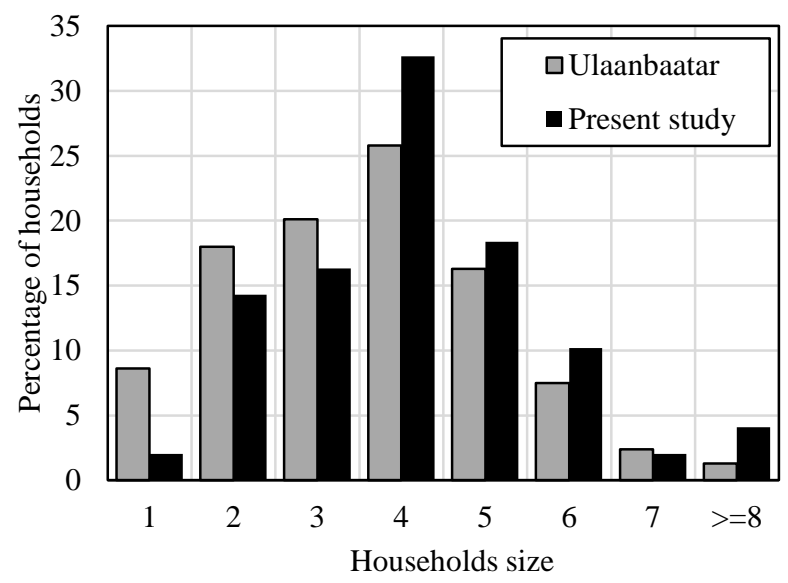

Fig. 2: Proportional distribution of household members in the sample and Ulaanbaatar ${ }^{32)}$

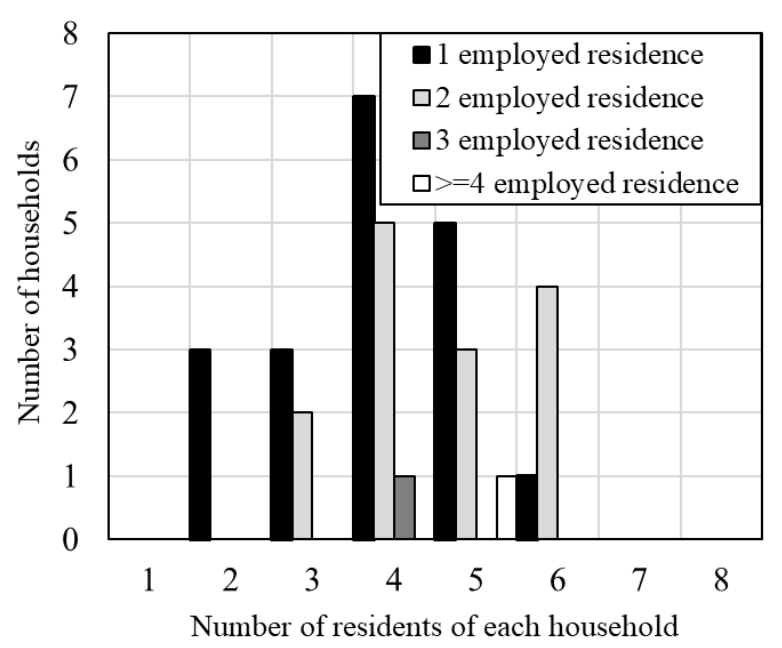

Fig. 3: Number of employed household members by household size

Source: National Statistical Office of Mongolia ${ }^{47}$ 


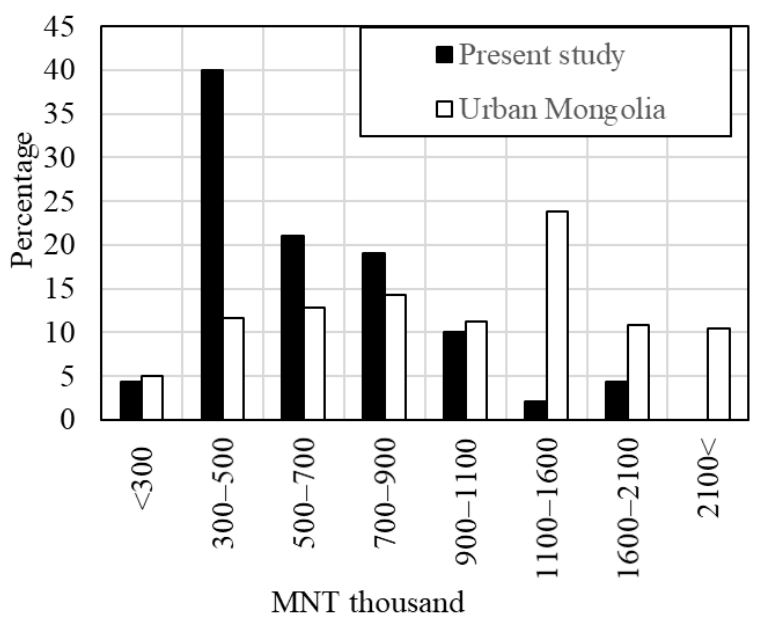

Fig. 4: Distributions of monthly household incomes in the sample $(n=49)$ and in Mongolia’s urban population $\left.{ }^{38}\right)$

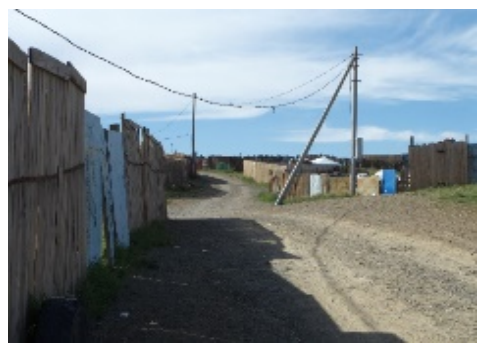

(a) Unpaved street

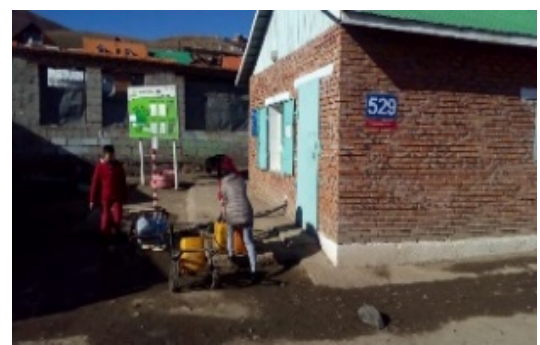

(b) Water kiosk

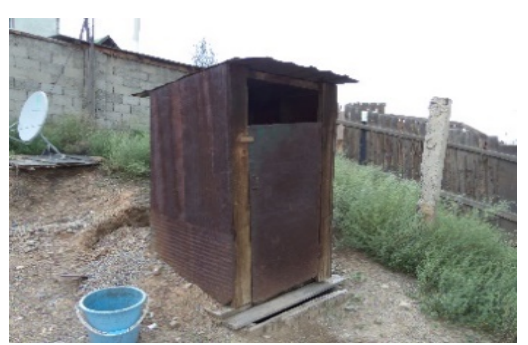

(c) Outdoor toilet

Fig. 5: Basic infrastructure in ger districts: (a) 18th khoroo, Songinokhairkhan district, (b) 19th khoroo, Chingeltei district, and (c) Gandan, Bayangol district. All photographs were taken by the authors on 17 August for (a), November 3 for (b) and 15 August for (c) in 2018.

to a central water supply. In addition, there are currently deep-well kiosks in Ulaanbaatar. The National Statistical Office of Mongolia reported that 712 water kiosks existed in Ulaanbaatar's ger districts in 2018 ${ }^{38)}$. The average distance from a ger to a water kiosk from which people transported water on foot was $600 \mathrm{~m}$; however, the distance of 5 gers exceeded $1 \mathrm{~km}$ because of the location of suburban districts having fewer water kiosks.

Sewerage sanitation was not provided in the ger districts; thus, all the surveyed households had an outdoor toilet in the same plot as their living space (Fig. 5(c)). In regard to bathing facilities, none of the surveyed gers had one, thus, $98 \%$ of respondents used public bathhouses, which have recently become popular for people in the ger districts. In 2019, Ulaanbaatar had 271 public bathhouses with a total capacity of 1,368 people ${ }^{38)}$.

The lack of these public water systems is partly due to the cold climate, which causes large freezing depth of during the winter of about $2.6 \mathrm{~m}$ to $3.8 \mathrm{~m}^{39}$. Thus, the construction and maintenance costs of these systems would be more expensive than those in mid-latitude areas.

\subsection{Structure and size of the gers}

The Mongolian Agency for Standardization and Metrology (MASM) ${ }^{4041)}$ stipulates the national standards of ger design, including materials, structure, and size of each part. Fig. 6 illustrates the structural design of a tandard ger based on the present survey with reference to (a)'s national standards ${ }^{40) 41}$. Figs. 7 and 8 show photographs of the exteriors and interiors of the participants in the study, respectively.

Some of the interviewees explained the typical construction process of the gers as follows. (1) The floor has seven interlocking flat wood plates, (2) the hana (made of several latticed wood pieces) is unfolded and formed into a circular wall, and (3) a khaalga (door) is connected to the two ends of the hana using a rope. Usually, the khaalga faces south. Then, (5) two pillars are erected in the centre of the hana to support the toono skylight), and the uni (poles) are connected to the interior sides of the hana, (6) the exterior of the entire structure is covered with esgii (layered felted wool insulation), and
(7) a busluur (rope) is hooped around the hana, tightened, and secured. All procedures can be completed within several hours with the assistance of two to four adults. This procedure is almost the same as those reported by Alexander et al. ${ }^{42)}$ and Maidar et al. ${ }^{5}$.

The national standards ${ }^{40} 41$ ) adopted the classification of the size of gers by number of lattice-shaped pieces named hana, used to make a round wall of a ger. There are nine categories, namely, three, four, extended five, six, eight, ten, twelve, fifteen, and twenty hana ger. Table 2 shows the distribution of ger types by this classification in the 49 gers examined by the authors. The data of national statistics $^{3)}$ are also included as a reference. As can be seen from the table, four, five, six, and eight hana gers are mainly used, and five hana gers account for more than half of the total.

Table 3 shows the dimensions of the gers measured by the authors and what is stipulated in the standards ${ }^{40) 41}$. The floor area, room volume, and area of the ger envelope exposed to outdoor air estimated based on the national standards are also included as essential variables for calculating the heating load. Although the design of the gers is highly standardised, the mean length of each part observed is slightly different from the standards mainly because of the backlash between parts connected by ropes. 


\subsection{Compositions of exterior cover and floor of gers}

Theoretically, the composition and materials of building envelopes are essential factors in determining the amount of heat loss of buildings in winter-namely heating load-and gers are usually enveloped in multiple layers of various materials. Therefore, we interviewed residents about their knowledge of the composition of their gers and the function of each layer. To this inquiry, all interviewees knew the type of materials used in their gers and had a common understanding of the function of each layer. Their answers about exterior cover for the winter season are summarised in Table 4. The standard thickness of layers stipulated in the national standards ${ }^{41)}$ is also included.

The thin white sheets called Gadne tsagaan burees were used as an outermost cover in all the surveyed gers for aesthetic purposes. Many interviewees explained that it was essential for the Mongolian people to make it a ger. Beneath this outer cover, a waterproofed sheet called a berzent is installed in most gers to prevent rain leakage and protect the indoor environment from cold winter winds. When this waterproof layer deteriorated over time, most households replaced it with a new one or replaced it with polyethylene sheets. On the other hand, nine residents said that they had left the deteriorated berzent in place, thinking it would help some heat insulation, and added a new one or new polyethylene sheets beneath the berzent.

The third layer is the felted wool sheets named esgii, which was used for insulation in 96\% of the surveyed gers. The materials of esgii are mostly brushed sheep wool ${ }^{43}$. This fabric usually consists of two layers for adequate thermal insulation in cold winters. In contrast, $4 \%$ of the surveyed households use a fabric named zulhai (carded wool) as an alternative to esgii because it is less expensive, although it is widely known for its less effective insulation performance.

In addition to the esgii insulation, some households used paper or polyethylene sheets, expecting an increase in insulation properties. A few interviewees stated that adding a polyethylene layer may cause condensation; thus, they switched the place of the polyethylene layer from the outer side to the inner side of the esgii during winter.

The majority of the innermost layer consists of white cotton sheets named dotor tsagaan tsavag and tuurga for roofing and walls, respectively. The main function of this layer is to prevent the felt sheets (esgii) from flaking off and falling into the room. Several households use carpets on their interior walls.

Table 5 compares the uses of esgii insulation in summer and winter. Most of the households used two layers of esgii in both seasons, and about $49 \%$ of the households made changes depending on the season. In addition, when we visited in the summer, most of surveyed households had rolled up the hem of wall layers to create openings near the floor for natural ventilation.

From an architectural perspective, dwellings are assumed permanent and constructed for long-term use.

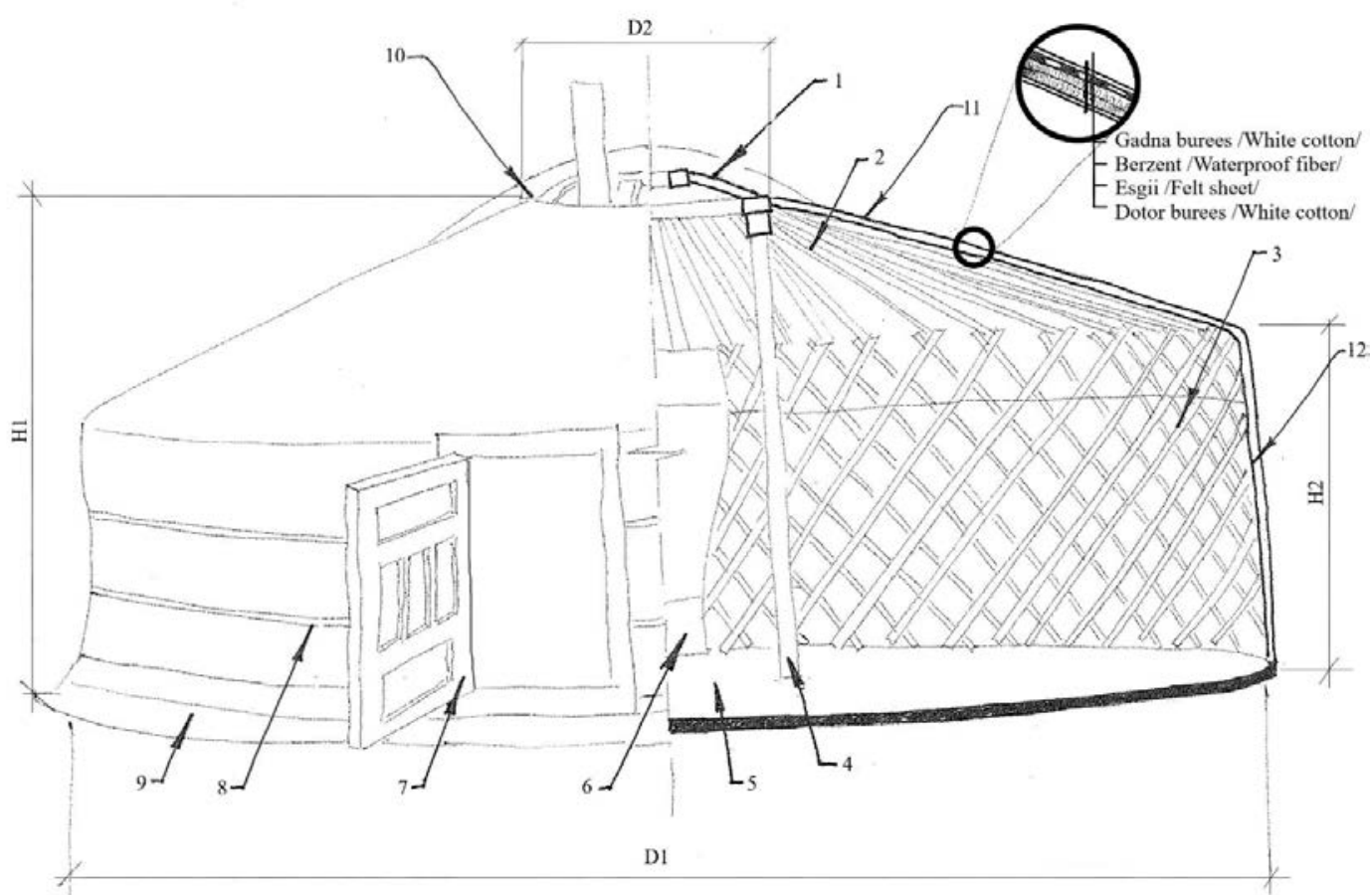

Legend: (1) toono (skylight) $\quad$ (2) uni (pole)

(6) hushig (inner curtain for wall)

9) hayaawch (lower edge of hana) (wall cover)

Fig. 6: Detailed structural illustration of a standard ger based on the study's observations and Mongolia's national standards; illustrated by the authors with reference of Mongolian Agency for Standardization and Metrology $(2003,2007)^{40441)}$

H1, H2, D1, and D2 correspond dimensions shown in Table 2. 


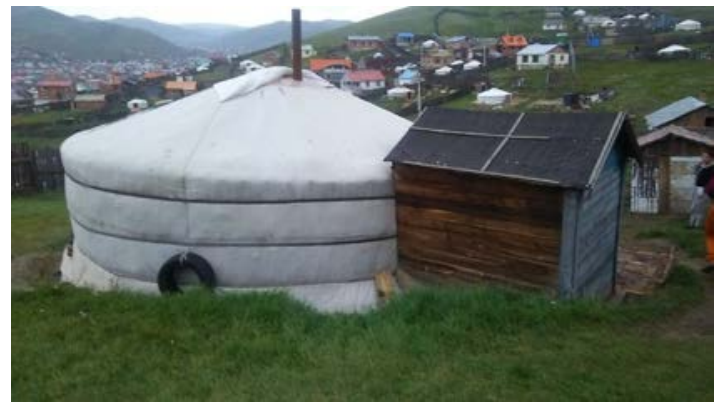

Fig. 7: Exteriors of gers in the 18th khoroo, Songino khairkhan district, Ulaanbaatar

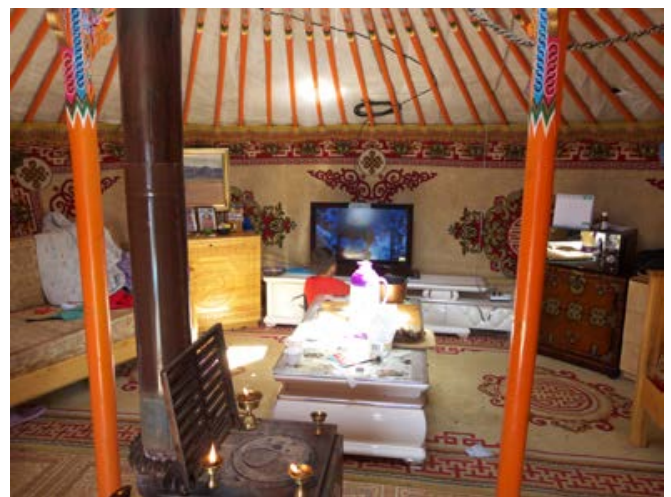

Fig. 8: Interior of a ger photographed during an interview in 18th khoroo, Sukhbaatar district, Ulaanbaatar

Source: Authors (photograph taken on 19 August 2018)
Table 2 Distribution of ger types by number of hana (wall unit)

\begin{tabular}{c|c|c|c}
\hline Type & $\begin{array}{c}\text { Present } \\
\text { study }\end{array}$ & $\begin{array}{c}\text { National } \\
\text { statistics }\end{array}$ & $\begin{array}{c}\text { Market price } \\
\text { observed }\end{array}$ \\
\hline Four & $10 \%$ & $17.4 \%$ & $2,000,000 \mathrm{MNT}$ \\
\hline Five & $84 \%$ & $77.0 \%$ & $\begin{array}{c}2,200,000- \\
2,500,000 \mathrm{MNT}\end{array}$ \\
\hline Six & $2 \%$ & $2.3 \%$ & \\
\hline Eight & $4 \%$ & $3.3 \%$ & \\
\hline
\end{tabular}

the most common covering because of financial limitations. Only one family had used laminate on concrete flooring. The floors of several gers were covered half with carpet or esgii futon because of cleaning difficulties related to their dirty coal-burning stoves. Most of the interviewees were frequently dumping ashes outside and bringing coal inside to the stove; thus, they replaced the top floor layer every year.

Regarding floor insulation, the current national standards did not include any description, probably because MASM's focus was on highly mobile nomadic gers. In rural areas, nomadic households usually insulate their floors with dung as accessible material. However, in urban areas, dung is less available. None of the surveyed

Table 3 Dimension of surveyed gers classified by number of hana with data of Mongolian standard ${ }^{36}$ )

\begin{tabular}{|c|c|c|c|c|c|c|c|c|}
\hline \multirow[t]{2}{*}{$\begin{array}{l}\text { Ger } \\
\text { type }\end{array}$} & \multicolumn{5}{|c|}{$\begin{array}{l}\text { Mean and standard deviation of size of each part; } \\
\text { values in parentheses indicate national standard }\end{array}$} & \multirow[t]{2}{*}{ Floor area } & \multirow{2}{*}{$\begin{array}{c}\text { Outer } \\
\text { surface } \\
\text { area }\end{array}$} & \multirow[t]{2}{*}{$\begin{array}{l}\text { Interior } \\
\text { volume }\end{array}$} \\
\hline & $\mathbf{H}_{1}$ & $\mathbf{H}_{2}$ & $\mathbf{D}_{1}$ & $\mathbf{D}_{2}$ & $n$ & & & \\
\hline $\begin{array}{l}\text { Four } \\
\text { hana }\end{array}$ & $\begin{array}{l}\text { Mean } 215 \mathrm{~cm} \\
\text { SD } 13 \mathrm{~cm} \\
(220 \mathrm{~cm})\end{array}$ & $\begin{array}{l}\text { Mean } 143 \mathrm{~cm} \\
\text { SD } \quad 3 \mathrm{~cm} \\
\\
\quad(145 \mathrm{~cm})\end{array}$ & $\begin{array}{lc}\text { Mean } 470 \mathrm{~cm} \\
\text { SD } \quad 7 \mathrm{~cm} \\
& (530 \mathrm{~cm})\end{array}$ & $\begin{array}{lc}\text { Mean } 113 \mathrm{~cm} \\
\text { SD } \quad 2 \mathrm{~cm} \\
\\
\quad(125 \mathrm{~cm})\end{array}$ & 4 & $22.6 \mathrm{~m}^{2}$ & $45.90 \mathrm{~m}^{2}$ & $39.10 \mathrm{~m}^{3}$ \\
\hline $\begin{array}{l}\text { Five } \\
\text { hana }\end{array}$ & $\begin{array}{l}\text { Mean } 243 \mathrm{~cm} \\
\text { SD } 14 \mathrm{~cm} \\
\quad(235 \mathrm{~cm})\end{array}$ & $\begin{array}{lc}\text { Mean } & 148 \mathrm{~cm} \\
\text { SD } & 4 \mathrm{~cm} \\
& (145 \mathrm{~cm})\end{array}$ & \begin{tabular}{|l} 
Mean $541 \mathrm{~cm}$ \\
SD $22 \mathrm{~cm}$ \\
$(620 \mathrm{~cm})$
\end{tabular} & $\begin{array}{l}\text { Mean } 133 \mathrm{~cm} \\
\text { SD } 7.5 \mathrm{~cm} \\
\quad(140 \mathrm{~cm})\end{array}$ & 36 & $30.9 \mathrm{~m}^{2}$ & $59.85 \mathrm{~m}^{2}$ & $55.00 \mathrm{~m}^{3}$ \\
\hline $\begin{array}{r}\text { Six } \\
\text { hana }\end{array}$ & $\begin{array}{l}\text { Mean } 237 \mathrm{~cm} \\
\text { SD cm } \\
\quad(250 \mathrm{~cm})\end{array}$ & \begin{tabular}{|cc} 
Mean & $157 \mathrm{~cm}$ \\
SD & $0 \mathrm{~cm}$ \\
& $(145 \mathrm{~cm})$
\end{tabular} & $\begin{array}{lc}\text { Mean } & 596 \mathrm{~cm} \\
\text { SD } & 0 \mathrm{~cm} \\
& (660 \mathrm{~cm})\end{array}$ & $\begin{array}{c}\text { Mean } 137 \mathrm{~cm} \\
\text { SD } 0 \mathrm{~cm} \\
(150 \mathrm{~cm})\end{array}$ & 1 & $34.2 \mathrm{~m}^{2}$ & $70.00 \mathrm{~m}^{2}$ & $64.93 \mathrm{~m}^{3}$ \\
\hline $\begin{array}{l}\text { Eight } \\
\text { hana }\end{array}$ & $\begin{array}{l}\text { Mean } 265 \mathrm{~cm} \\
\text { SD } 14 \mathrm{~cm} \\
(255 \mathrm{~cm})\end{array}$ & \begin{tabular}{|l} 
Mean $148 \mathrm{~cm}$ \\
SD $4 \mathrm{~cm}$ \\
$(145 \mathrm{~cm})$
\end{tabular} & \begin{tabular}{|lr} 
Mean $633 \mathrm{~cm}$ \\
SD $22 \mathrm{~cm}$ \\
$(680 \mathrm{~cm})$
\end{tabular} & \begin{tabular}{|lr} 
Mean $165 \mathrm{~cm}$ \\
SD $7.5 \mathrm{~cm}$ \\
\\
$(160 \mathrm{~cm})$
\end{tabular} & 2 & $36.3 \mathrm{~m}^{2}$ & $71.00 \mathrm{~m}^{2}$ & $70.00 \mathrm{~m}^{3}$ \\
\hline
\end{tabular}

$\mathrm{H}_{1}$ : height of floor to urkh (skylight cover), $\mathrm{H}_{2}$ : height of wall, $\mathrm{D}_{1}$ : diameter of floor, $\mathrm{D}_{2}$ : diameter of urkh,

$n$ : number of surveyed gers

In contrast, ger residents often adapt the envelopes to fit seasonal differences in a similar manner to how people change their types of clothing to adapt to weather and climate. Nevertheless, it is noteworthy that about $25 \%$ of the households spent winter with just one layer of felt sheeting because of financial limitations.

Table 6 lists the materials used for the floor in the surveyed gers with the ratio of usage. Although the national standards ${ }^{40)}$ stipulate that a ger's floor must be wood, more than half of the surveyed gers were built on bare ground with only a thin layer of linoleum, which was participants used any particular insulation layer on the floor. Approximately $26 \%$ of the floors were covered with a few layers of cardboard, and just $6 \%$ of the floors were insulated with thin foam and foil sheeting.

In addition to the exterior cover and floor, the residents explained the necessity of preventing cold drafts in winter from seeping in through the interface between the lower edge of the walls (hana) and the floor. The national standards require this interface to be blocked with esgii and berzent. The interviewees reported four ways to 
Table 4. Layers used in gers for envelope during the winter

\begin{tabular}{c|c|c|c|c}
\hline Layers & Name & Explanations from interviewees & $\begin{array}{l}\text { Ratio of usage } \\
\text { in surveyed gers }\end{array}$ & $\begin{array}{c}\text { Standard } \\
\text { thickness }\end{array}$ \\
\hline Cotton & Gadne tsagaan burees & $\begin{array}{c}\text { Thin white sheet used for outermost cover } \\
\text { for aesthetic purpose }\end{array}$ & $100 \%$ & $0.3 \mathrm{~mm}$ \\
\hline Tarpaulin & Berzent & Water protection & $65 \%$ & $1.0 \mathrm{~mm}$ \\
\hline Polyethelene & & Optionally used for water protection & $20 \%$ & \\
\hline Paper insulation & Insulation & $18 \%$ & \\
\hline Felt sheeting & Esgii & Insulation & $96 \%$ & $15.0 \mathrm{~mm}$ \\
\hline Polyethelene & & $\begin{array}{c}\text { Optionally used for moisture barrier to } \\
\text { avoid condensation }\end{array}$ & $20 \%$ & \\
\hline Cotton & Dotor tsavag and Tuurga & $\begin{array}{c}\text { Thin white sheet mostly used as innermost } \\
\text { layer for roofing and walls }\end{array}$ & $94 \%$ & $0.3 \mathrm{~mm}$ \\
\hline Carpet & & Interior decoration and wall insulation & $20 \%$ & \\
\hline Synthetic carded wool & Zulhai & Insulation & $6 \%$ & $10.0 \mathrm{~mm}$ \\
\hline
\end{tabular}

*Each row is sorted in order from the outside to inside based on the place of each layer.

improve airtightness, as shown in Table 7. About one-half of the households used old flour sacks instead of berzent.

Notably, 21 of the 49 households attached a temporary anteroom to the entrance of their gers to reduce heat loss and cold ingress through the door in winter, as depicted in Fig. 7. In most cases, this windbreak room was made of single-layer plywood boards, having about $1.7 \mathrm{~m} \times 2.3 \mathrm{~m}$ of floor area and about $1.8 \mathrm{~m}$ height. They were used to store coal, wood, and other supplies. Some of the interviewees dismantled the rooms for the summer and set them aside.

Table 5. Breakdown of number of felt sheets (esgii) in sampled gers for summer and winter seasons

\begin{tabular}{c|c|c}
\hline Number of layers & $\begin{array}{c}\text { During } \\
\text { summer }\end{array}$ & During winter \\
\hline One & $45 \%$ & $25 \%$ \\
\hline Two & $51 \%$ & $62 \%$ \\
\hline Three & $4 \%$ & $13 \%$ \\
\hline Zero & $0 \%$ & $0 \%$ \\
\hline
\end{tabular}

Table 6. Materials used for floor in surveyed gers during winter

\begin{tabular}{c|c}
\hline Type of covering & Ratio of usage \\
\hline Fully covered carpet & $57 \%$ \\
\hline Half covered carpet & $15 \%$ \\
\hline Linoleum & $89 \%$ \\
\hline Laminate & $2 \%$ \\
\hline Wood floor & $51 \%$ \\
\hline Thin insulation pad & $6 \%$ \\
\hline Cardboard box & $26 \%$ \\
\hline Reflective insulation & $6 \%$ \\
\hline Dry livestock dung & $4 \%$ \\
\hline Concrete & $19 \%$ \\
\hline Condensed gravel & $36 \%$ \\
\hline
\end{tabular}

Table 7. Methods used in surveyed gers for improving airtightness of joints between wall and floor

\begin{tabular}{c|c}
\hline Methods & Ratio of usage \\
\hline used floor sack & $47 \%$ \\
\hline waterproof fabric & $39 \%$ \\
\hline felted and waterproofed fabric & $9 \%$ \\
\hline old clothing and waterproofed fabric & $6 \%$ \\
\hline
\end{tabular}

\subsection{Lifespan of gers}

The durable lifespan of a ger is not clearly stated in the national standards ${ }^{4041) 44) 45)}$. Nevertheless, the Mongolian Agency for Standardization and Metrology ${ }^{46}$ advises users to test the performance and quality of felt sheets (esgii) every five years. A few interviewees working in shops and in manufacturing of gers also explained to the authors that esgii might retain their original insulating abilities for about five years. They also recommended replacing the waterproof layer every two years. Regarding the wood components of the structure, they stated that it should last a human lifetime depending on the use and maintenance status.

Fig. 9 shows the scatter plot between the used period of the felt sheets (esgii) and years living in the current ger. Although the gers were originally temporary shelters for nomads, it is noteworthy that $43 \%$ of households have lived in their current respective ger for over 10 years. Regarding the replacement of esgii, $8.2 \%$ of households that had been in the current ger for more than 10 years had replaced the esgii within the past five years as the national standard advised. On the other hand, about 55\% of households living in the current ger for more than 5 years have never changed felt sheets. Reasons why people did not replace the felt were 1) they did not have the financial possibility, or 2) they thought it was not necessary to be replaced.

Meanwhile, Kawagishi et al.7) reported that nomads relocated approximately four times a year, depending on their livestock, to establish camps in new locations with appropriate natural conditions. On the other hand, 67\% and $24 \%$ of the surveyed gers were rebuilt at the same plot twice a year and every year, respectively, to dry the felt cover and improve the insulation. This suggests that even though gers have become homes of permanent residents in Ulaanbaatar, the regular procedures of reassembling the components regularly is maintained. This fact cannot be ignored for the development of methods for improving the thermal performance of gers.

\subsection{Factors influencing the purchase decision of esgii}

As mentioned before, the ger design is highly standardised; thus, people purchasing a new ger usually first select the desired size from multiple options, and then 
select each component individually from various stores and manufacturers. With this background, the authors asked residents about the factors influencing the selection of felt sheets (esgii), which are critical parts for the thermal performance of gers. About $69 \%$ of respondents were unsure how to answer this question, and only 15 respondents explained their decision-making process. Table 8 shows a summary of their answers. Cost was the biggest concern, followed by physical characteristics, such as density, colour, and odour. Vendors' explanations were also considered in the selection of products. Esgii were usually brown or white, and the interviewees assumed that the heavy and brown esgii was of high quality. One interviewee, who did not like the natural odour of the esgii, stated that 'non-smelly' esgii were better. In contrast, another person preferred 'smelly' esgii because he thought that the odour indicated that the wool had not been washed, which preserved the wool's natural lanoline, making it stronger for frequent reassembling. In short, despite the fact that esgii are almost the only component of the thermal insulation of the envelope, there is little interest in their physical properties.

\subsection{Affordability}

As mentioned in section 2.2, the authors investigated the selling prices of gers in Naran Tüul Market in August 2018. Complete ger kits that are ready to build and all types of replacement parts and tools, including uncut esgii, are sold there. Parts can also be purchased from specialists.

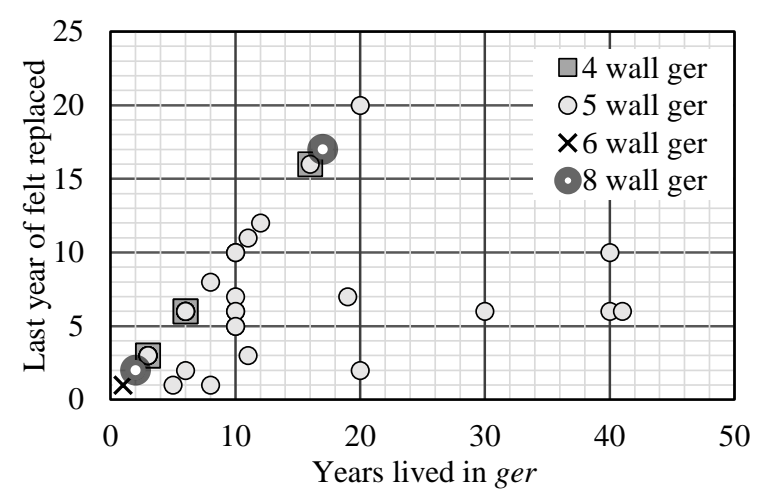

Fig. 9: Relationship between the replacement life of felt sheeting and number of years living in the current ger

Table 8. Factors influencing the decisions about felt sheeting purchases ( $n=15$ households)

\begin{tabular}{c|c}
\hline \multicolumn{2}{c}{ purchases $(n=15$ households } \\
\hline Factors & Ratio \\
\hline Cost & $67 \%$ \\
\hline Vendor advice & $27 \%$ \\
\hline Preference for pickled felt (esgii) & $7 \%$ \\
\hline Density & $40 \%$ \\
\hline Colour & $40 \%$ \\
\hline Odour & $13 \%$ \\
\hline Thickness & $7 \%$ \\
\hline Made in Mongolia & $13 \%$ \\
\hline
\end{tabular}

The larger gers were usually pre-ordered.

According to this observation, although there was a large variety of options for buying ger products, significant price cuts were limited to large purchases, and there was not much difference in prices between stores. The typical prices of the complete ger sets observed are shown in the rightmost column of Table 2.

The price of most popular five-hana gers ranged from about $2,200,000$ to $2,500,000$. In contrast, the price of one-layer felt sheets (esgii) for a five-hana ger was about MNT 720,000 , which is about $28 \%$ of the total price. Considering that one-layer esgii for a four-hana ger cost about MNT 520,000, the standard price of esgii, including cutting and sewing per $1 \mathrm{~m}^{2}$, is about MNT 11,000 to 12,000 , which is equivalent to approximately US\$4.

The low cost of a ger as a home for settlers from rural to urban areas is noteworthy. Using the data of the median monthly household income in our sample-MNT 600,000 - shown in Fig. 6, the price of a small but relatively comfortable ger can amount to about three- or four-months' household income. Although gers are temporary and mobile tents that require continual maintenance, the cost is relatively affordable, probably because of the highly standardised design and components that rely on domestic products, such as sheep wool.

On the other hand, the current average cost of an apartment per unit floor area reported by the National Statistical Office of Mongolia ${ }^{47)}$ is MNT 2,250,000/m², indicating an apartment of about $45 \mathrm{~m}^{2}$ costs about MNT 101.25 million. It is about 14 times the annual income of the surveyed households. Therefore, apartments are beyond the financial reach of many people living in the ger districts of Ulaanbaatar.

\section{Residents' behaviours and perceptions related to space heating}

\subsection{Uses of interior space}

As previous studies such as Omoya ${ }^{6}$, Maidar et al.5), and Alexander et al. ${ }^{42)}$ reported, the interior spaces of the surveyed gers were generally organised into several functional zones for activities without partitioning. Furthermore, furniture placement in the surveyed gers was similar. Fig. 10 illustrates the typical floor plan of gers.

Even though the survey was conducted in summer when the daily mean outdoor temperature was around $17^{\circ} \mathrm{C}$, all the gers had a coal stove in the centre of their room and used it for cooking. A pantry was on the right with the entrance behind it, a sink and a clothes washer were on the left, and a television was opposite the entrance. Beds were placed along the walls, except by the entrance door. A table was usually near the centre of a ger but was placed next to the walls in several gers. The functional usage of the space was determined by the location of the furniture; a space near a television set, table, and chairs was for meals and gatherings of a family and for study, while they used beds for sleeping, sitting, and as a workbench.

Regarding the position of the entrance, Alexander et al. ${ }^{42)}$ indicated that ger entrances ideally face south to avoid cold north wind and introduce solar radiation to the interior space. In contrast, most of the surveyed participants basically followed this practice; however, the 
orientation of a door in 95\% of the surveyed gers was slightly modified from southeast to southwest due to the geographical features of plots and neighbourhoods.

Table 9 lists the ownership of household appliances and furnishings of the surveyed gers. The data of a past survey conducted in 2016 on 285,622 gers $^{48)}$ throughout the entire country-including nomadic gers-were also included as a reference. Televisions, washing machines, refrigerators, and electric kettles were the most common household appliances. The smaller value of refrigerators in the past survey compared to the current study is probably caused by the fact that nomadic gers have limited electric supply compared to urban settlers.
The variety of home appliance types in the surveyed gers suggests participants' relatively moderate standard of living even though they were in unplanned settlements with limited infrastructure. Remarkably, the total purchase value of electrical appliances in a household was estimated to be the same or much higher than the price of their ger. As previously mentioned, a five-hana ger costs about MNT 2,200,000 to MNT 2,500,000 (US\$ 780 to 900 ), and the retail prices of LCD or plasma televisionswhich are owned by 47 of the households-currently range from about MNT 330,000 to MNT 16,000,000 at popular electronic stores in Ulaanbaatar. This price

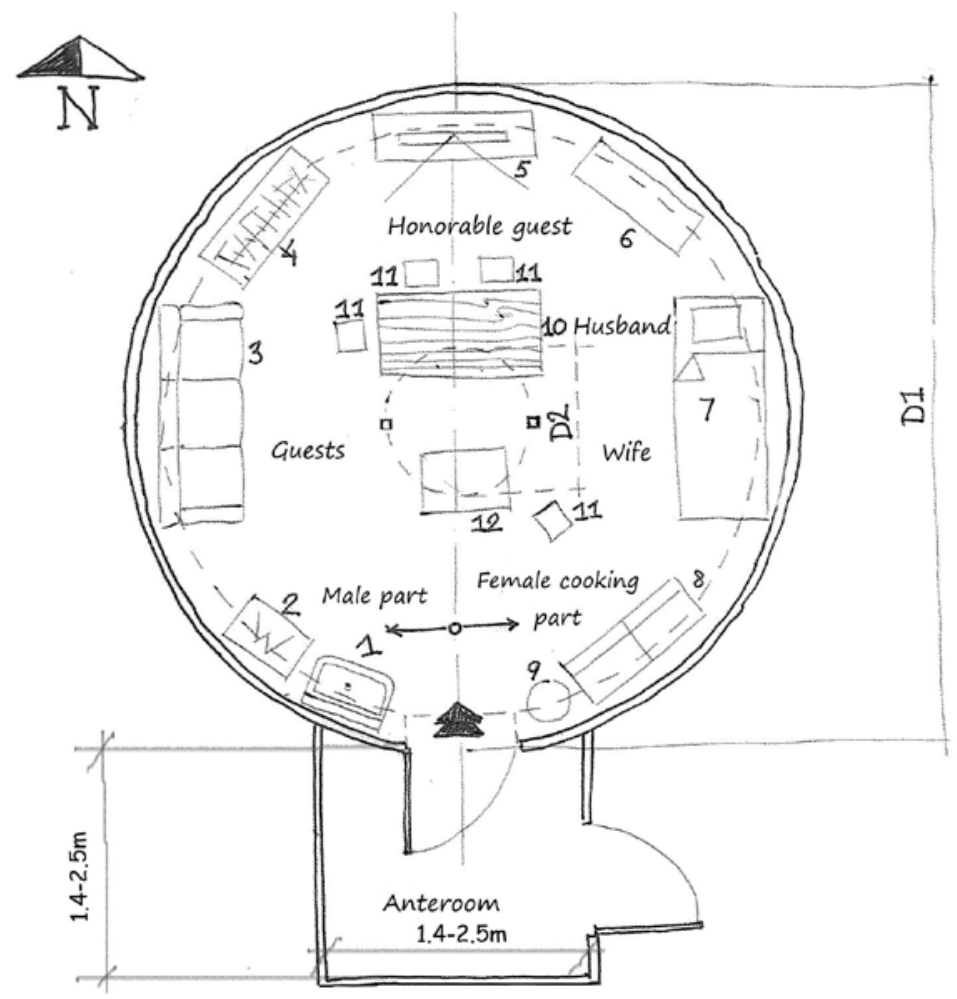

Legend:

(1) Sink

(2) Washing machine

(3) Sofa or bed

(4) Closet

(5) Television set

(6) Avdar (wood chest)

(7) Bed

(8) Pantry

(9) Cistern

(10) Table

(11) Chair

(12) Stove

Dimension D1 and D2 shown in Table 2

Fig. 10: The usual interior layout of the surveyed gers. Source: Authors

comparison again highlights the affordability of gers. In addition, about $53 \%$ of the households owned at least one car, which certainly costs more than a ger.

\subsection{Types of space heating devices}

Most interviewees explained that the heating period of their gers was from September to the beginning of June. Fig. 11 and Table 10 show the major devices used for heating in the surveyed gers. Coal stoves, including both conventional and improved stoves, were the most common, and 31\% used stoves for cooking throughout the year. In addition, about 59\% of the surveyed households owned an improved stove, and $4 \%$ of surveyed households used an improved stove with an electric heating device overnight with subsidies. However, they stated that their electrical heating devices were not powerful enough to heat the entire ger; thus, they were used only during nights as an auxiliary heater.

Regarding the policy implementation to mitigate severe air pollution, the Mongolian government sold refined coal with the support of the Asian Development Bank and JICA during 2017-2018. Ulaanbaatar and the central Mongolian government subsequently prohibited raw coal usage in six major Ulaanbaatar districts ${ }^{49}$ since 15 May 2019, and proposed using refined coal instead. Although the past survey ${ }^{50)}$ reported that $63.8 \%$ of 120 surveyed households evaluated the refined coal as good or very good, the present survey found that only two out of 49 households used refined coal, and they were not satisfied with its heating performance, claiming that a larger amount of refined coal is needed than raw coal to achieve the same heating power.

\section{Residents' perception of coal stoves}

Table 11 shows the perception towards improved coal stoves, which are supposed to have higher energy efficiency and lower emissions of air pollutants than conventional ones. This suggests that most owners were 
satisfied with their improved stoves. Ten household members stated their reasons for a positive evaluation, such as the improved stove was energy efficient and the burning time was longer than that of conventional stoves; thus, they did not need to add coal so often. On the other hand, 9\% of household members were not satisfied because of the slightly complex procedure for lighting improved stoves compared to the conventional ones. The improved stoves require burnt embers and ashes to be removed, and occupants must completely clean the stove before ignition. They also mentioned that adjusting the burning process of the improved stove was more difficult, and sometimes overheated or excessively ignited the stoves.

In contrast, representative interviewees of each ger with a conventional stove were asked about their interest in the improved stove. Twelve of the fifteen households expressed interest in improved stoves. Five interviewees pointed out that conventional stoves were more likely to cause burn injury, particularly for children, because a hot, wide iron plate is directly exposed to the room air. Nevertheless, three interviewees stated that the improved stoves could not be used for cooking in the case of large families, so they preferred a conventional stove having a wider upper plate that is suited to a big pot; one ger had an improved stove the previous year but had replaced it with a conventional stove.

With regard to the function of coal stoves used in the surveyed gers, there were few functions to adjust the combustion intensity to realise the desirable room air temperature, unlike air conditioners. Coal stoves continue to burn after ignition until the coal is burned. During the heating season, the surveyed households built fires three or four times a day, and about $17 \%$ of them used their stoves all day because someone was always at home. Most interviewees estimated that it took about 20 to 30 minutes to warm the entire ger after ignition, and they considered this duration to achieve warm indoor conditions as acceptable. The reason for this positive evaluation, despite the extremely low outside air temperature in winter and the low thermal performance of ger envelopes, is probably due to the heat released through the radiation and convection from less insulated floors that store heat while stoves are burning.

Regarding the methods to modulate indoor air temperature, half of the owners of an improved stove utilised a plate installed over a chimney duct that can be opened and closed for regulation. Twenty-six percent of families closed part of the section between the stove and chimney by using additional tools when they needed to weaken the stove fire. Fourteen and twenty percent of households modulated the fire by the stove door and amount of fuel used, respectively. Nevertheless, even more surprisingly, $18 \%$ of households sometimes opened the door or skylight (toono) and directly introduced cold outdoor air to avoid overheating. This suggests that gers with low airtightness and low thermal insulation require a stove with an excessive heating capacity compared to ordinary buildings with the same room volume, resulting in a large amount of wasted fuel and pollutant emissions.
It is noteworthy that $20.4 \%$ of the residential fire accidents in Mongolia in 2018 were stove-related, 27.6\% of which were due to fire leakage from combustible equipment and blowing ashes ${ }^{51)}$. Furthermore, the use of coal stoves requires regular physical effort to bring the coal indoors. About $60 \%$ of the surveyed households purchased coal and wood in $10 \mathrm{~kg}$ to $30 \mathrm{~kg}$ sacks every three to five days from retailers and transported it to their

Table 9. Ownership of appliances/furniture observed in the sampled gers compared to the Bulgan study (2016)

\begin{tabular}{|c|c|c|}
\hline Items & $\begin{array}{c}\text { Present } \\
\text { study }\end{array}$ & Bulgan $^{62)}$ \\
\hline \multicolumn{3}{|l|}{ Appliances } \\
\hline Television & $100 \%$ & $96 \%$ \\
\hline Refrigerator & $100 \%$ & $59 \%$ \\
\hline Washing machine & $92 \%$ & $67 \%$ \\
\hline Electric kettle & $84 \%$ & $73 \%$ \\
\hline Rice cooker & $68 \%$ & $59 \%$ \\
\hline Electric hot pot & $64 \%$ & $68 \%$ \\
\hline Electric stove & $59 \%$ & $15 \%$ \\
\hline Freezer & $30 \%$ & $42 \%$ \\
\hline Oven & $22 \%$ & $11 \%$ \\
\hline Portable gas stove & $20 \%$ & - \\
\hline Vacuum cleaner & $18 \%$ & $30 \%$ \\
\hline Computer & $9 \%$ & - \\
\hline Microwave oven & $9 \%$ & - \\
\hline Music player and speaker & $4 \%$ & $21 \%$ \\
\hline \multicolumn{3}{|l|}{ Furniture } \\
\hline Stool chair & $100 \%$ & - \\
\hline Cupboard & $97 \%$ & - \\
\hline Television stand & $97 \%$ & - \\
\hline Small table & $81 \%$ & - \\
\hline Bed & $75 \%$ & - \\
\hline Armchair & $72 \%$ & - \\
\hline Sofa & $59 \%$ & - \\
\hline Dresser & $54 \%$ & - \\
\hline Dining table & $48 \%$ & - \\
\hline Avdar (chest) & $45 \%$ & - \\
\hline \multicolumn{3}{|l|}{ Other } \\
\hline Car & $53 \%$ & - \\
\hline
\end{tabular}

home in their cars or on foot. The remaining $40 \%$ of the households bought coal by the ton, which was delivered to their plots by the retailers using small trucks (known as 'porters').

Although current gers located in the ger districts in Ulaanbaatar can be recognised as temporary housing during the transition from nomadic to urban settled life, 


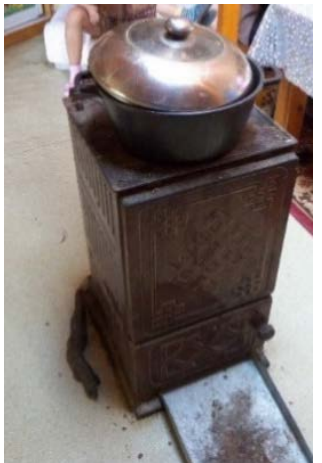

(a) Improved stove

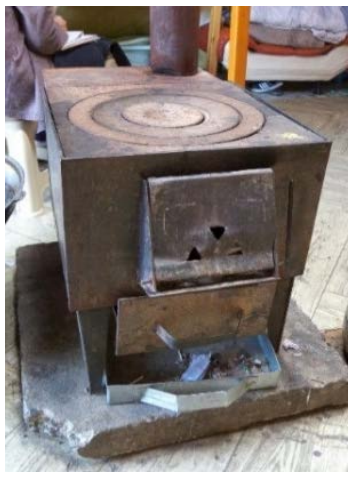

(b) Conventional stove

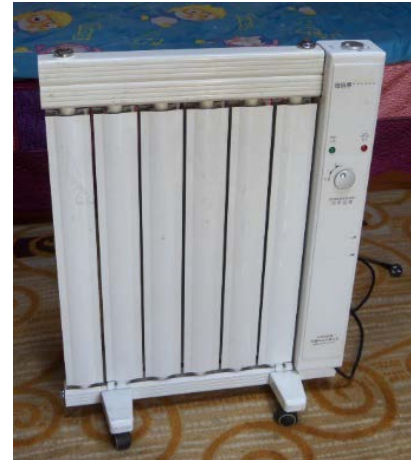

(c) Electrical radiant heater

Fig. 11: Types of heating devices used in the surveyed gers. Source: Authors (photograph taken on 2018)

considering the fact that many people have been living in gers for more than 10 years, policy implementation to improve the current living quality of gers is strongly needed. In particular, the replacement of current coal stoves with safer, more energy efficient, and environmentally friendly heating appliances should be considered as an effective measure to be taken.

\subsection{Fuel consumption in the surveyed gers}

The authors asked residents about the quantity of fuels for space heating. The average monthly consumption of raw coal and wood in the surveyed gers using conventional stoves in winter were 3.0 tons and $3.3 \mathrm{~m}^{3}$, respectively; in contrast, gers using the improved stoves consumed on average 2.5 tons and $2.5 \mathrm{~m}^{3}$, respectively. These values are almost comparable to the previous survey of the Asian Development Bank and JICA during 2017-2018 ${ }^{50)}$. Table 12 shows the statistics of the annual energy consumption for heating in 48 gers using coal stoves, including both conventional and improved ones. The data were estimated for not only the entire sample but also two groups categorised by the type of stoves under the assumption of calorific values of $20 \mathrm{MJ} / \mathrm{kg}$ and 14.4 $\mathrm{MJ} / \mathrm{kg}$ for coal and wood and density of wood chips of $600 \mathrm{~kg} / \mathrm{m}^{3}$. Note that even though 48 out of 49 households used a coal stove as a primary measure, they also used wood in addition to coal to ignite their stove.

Based on the average annual fuel consumption per floor area and heating degree hours derived from the annual weather data of Ulaanbaatar in 2018, the authors calculated the heat loss coefficient of a ger under the assumption of an indoor heating temperature of $18{ }^{\circ} \mathrm{C}$. This rough estimation was $4.28 \mathrm{~W} / \mathrm{m}^{2} \mathrm{~K}$, which is almost nine times the value required for newly built houses in Hokkaido, Japan ${ }^{52)}$.

The average consumption per unit floor area of gers using improved stoves is smaller by $18 \%$ than that for gers using conventional ones. Nevertheless, the standard deviation of each category is relatively large compared to the average, suggesting a diverse distribution of energy consumption. The authors examined the factors that may cause differences in energy consumption by assessing the correlation coefficients with building and behaviour
Table 10. Breakdown of primary space heating measures in the sampled gers $(n=49)$.

\begin{tabular}{lc}
\hline \multicolumn{1}{c}{ Items } & Proportion \\
\hline Improved coal stove & $59 \%$ \\
\hline Conventional coal stove & $35 \%$ \\
\hline Improved stove + Electric heater & $4 \%$ \\
\hline Wood stove & $2 \%$ \\
\hline
\end{tabular}

Multiple devices were used for major heating devices in 2 gers.

Table 11: Perception on improved stoves among representative members of each household in the survey $(n=34)$

\begin{tabular}{lc}
\hline \multicolumn{1}{c}{ Answers } & Proportion \\
\hline Very satisfied & $46 \%$ \\
\hline Satisfied & $31 \%$ \\
\hline Slightly satisfied & $14 \%$ \\
\hline Slightly unsatisfied & $3 \%$ \\
\hline Unsatisfied & $6 \%$ \\
\hline Very unsatisfied & $0 \%$ \\
\hline
\end{tabular}

conditions. However, there was no definite correlation with the size of the gers, that is, envelope surface area per indoor volume, heating hours, number of occupants, and thickness of ger envelopes. One possible reason why the energy consumption showed little correlation with these variables is that currently used coal stoves almost lack the ability to flexibly control the fire intensity to realise the target room air temperature. Thus, the combustion state and fuel use were highly dependent on how residents feed fuel to their stoves. If the fire is too strong, residents sometimes need to open a door or skylight to cool down the room air, as previously mentioned. This result also implies that even though the insulation performance of ger envelopes was drastically improved, significant energy savings would be rarely realised as far as current coal stoves are used.

\subsection{Winter clothing worn by residents of gers}

The authors asked residents about usual clothes worn inside their gers during winter, and estimated the total amount of thermal insulation of winter clothing as clo 
Table 12. Statistical summary of annual energy consumption of the surveyed gers using coal stoves for space heating

\begin{tabular}{|c|c|c|c|c|c|c|}
\hline & \multicolumn{3}{|c|}{ Annual energy consumption [GJ/year] } & \multicolumn{3}{|c|}{ Annual energy consumption per floor area $\left[G J / \mathbf{m}^{2}\right.$ year] } \\
\hline & Imp. stove & Con. stove & Total & Imp. stove & Con. stove & Total \\
\hline Average & 71.07 & 85.49 & 75.43 & 2.30 & 2.79 & 2.51 \\
\hline Median & 65.28 & 94.56 & 65.28 & 2.11 & 2.33 & 2.22 \\
\hline $\begin{array}{l}\text { Standard } \\
\text { deviation }\end{array}$ & 27.06 & 36.39 & 32.25 & 0.91 & 1.44 & 1.13 \\
\hline Maximum & 141.12 & 154.56 & 154.56 & 4.57 & 5.48 & 5.48 \\
\hline Minimum & 24.00 & 32.64 & 24.00 & 0.78 & 1.06 & 0.78 \\
\hline$n$ & 31 & 17 & 48 & 31 & 17 & 48 \\
\hline
\end{tabular}

values based on ASHRAE Standard 55-2010 ${ }^{53)}$. Fig. 12 presents the relationship between clo values and the age of residents. Note that the clo values of standard western business attire of a suit and tie are about 1.0 equivalent to $0.155 \mathrm{Km}^{2} / \mathrm{W}$. In contrast, the current survey shows wide variation from 0.2 clo to 1.83 clo. The clo values of female elder occupants were generally higher than those of others, while residents younger than 20 years old showed slightly higher values than middle-aged people. The median clo values of all respondents for males and females were 0.64 $(n=23)$ and $0.55(n=47)$, respectively. These values are similar to those reported by Schiavon et al. ${ }^{54)}$, where clo median values of female and male observed in office buildings located in California and Michigan in the U.S., Canada, and Australia during winter were $0.67(\mathrm{n}=2786)$ and $0.63(n=3547)$, respectively. Considering the low thermal performance of ger envelopes-self-assembled from vernacular materials and involving daily use of outside toilets which caused frequent openings and closings of a door-it is surprising that many ger residents spent time wearing light clothes in midwinter. Such a situation is underpinned by the excessive heating power of coal stoves, resulting in a large wasting energy.

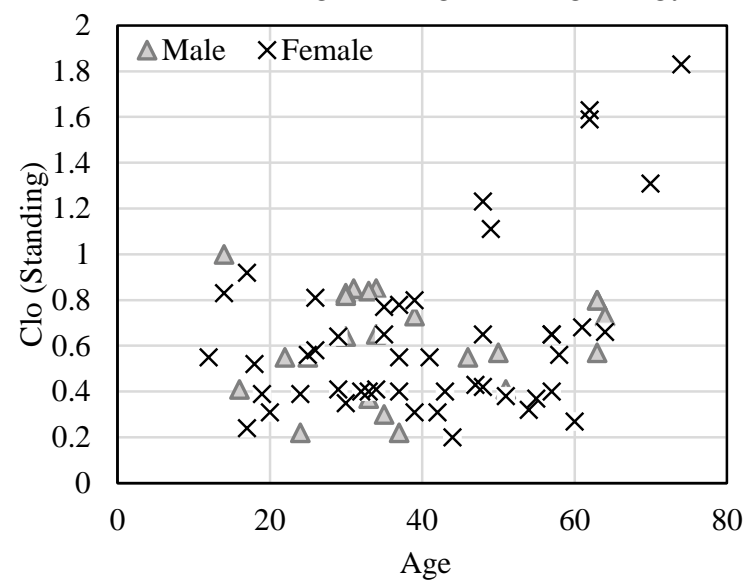

Fig. 12: Relation between clothing insulation and occupants age (Female $n=47$; Male $n=23$ )

\subsection{Residents' perception of indoor thermal comfort in winter}

The perception of indoor thermal comfort during winter in terms of temperature (hot or cold), humidity (moist or dry), wind speed, and overall satisfaction

(comfort or discomfort) was observed by five questions, which were partly based on the ASHRAE standard 55-
Table 13. Distribution of responses to the question: 'How do you rate the inside temperature of your ger during the winter?' (n=67)

\begin{tabular}{l|c}
\hline Response & Proportion \\
\hline Often too hot & $6 \%$ \\
\hline Occasionally too hot & $16 \%$ \\
\hline Occasionally too hot and too cold & $54 \%$ \\
\hline Neutral & $0 \%$ \\
\hline Occasionally too cold & $9 \%$ \\
\hline Often too cold & $15 \%$ \\
\hline
\end{tabular}

Table 14. Distribution of responses to the question: 'How do you evaluate the overall thermal comfort level of the inside environment in your ger during the winter?' (n=67)

\begin{tabular}{l|r}
\hline Response & Proportion \\
\hline Very comfortable & $15 \%$ \\
\hline Comfortable & $59 \%$ \\
\hline Slightly comfortable & $11 \%$ \\
\hline Slightly uncomfortable & $8 \%$ \\
\hline Uncomfortable & $7 \%$ \\
\hline Very uncomfortable & $0 \%$ \\
\hline
\end{tabular}

2004 ${ }^{53)}$. This paper presents some of the results.

Table 13 shows the distribution of responses to the question: 'How do you rate the inside temperature of your ger during the winter?' About $85 \%$ of the interviewees chose 'either too cold or too hot', suggesting significant fluctuations of room air temperature. According to interviewees, the indoor temperature quickly drops when they open a door or the coal in the stove is depleted. However, none of the interviewees stated that they felt 'often too cold', but about $76 \%$ stated that it 'often or occasionally felt too hot'. Taken together, these responses imply that coal stoves with excessively high heating capacity for small gers are being used to compensate for the low thermal performance of the ger envelopes, that unstable heat power of the coal stove are affected by available fuel, and that frequent inflows of cold air enter when the exterior door are opened.

Table 14 shows the distribution of responses to the question: 'How do you evaluate the overall thermal comfort level of the inside environment in your ger during the winter?' This question was used to evaluate overall thermal comfort satisfaction. About $74 \%$ of the interviewees chose 'comfortable', although just 15\% 
evaluated the temperature as neutral (no temperature discomfort) to the question about temperature rate (Table 13). This suggests that overheating by a powerful stove might be perceived as good under extremely cold outdoor conditions.

\subsection{Residents' plan to improve quality of life}

Table 15 shows the distribution of responses to the question: 'Do you plan to improve your living conditions?' The answers reflect people's desire for a more comfortable environment and the reality that it is difficult to achieve. About $8 \%$ of the interviewees were interested in relocating to an apartment equipped with a shower/tub, toilet, and central heating system. Four percent of the interviewees were interested in purchasing a larger ger.

Table 15. Distribution of responses to the question: 'If you have any plans to improve your living conditions, what type of plan do you have?' (asked without a prompt)

\begin{tabular}{l|c}
\hline Response & Proportion \\
\hline Move to an apartment & $8 \%$ \\
\hline Move to a Baishin & $12 \%$ \\
\hline Move to a larger ger & $4 \%$ \\
\hline $\begin{array}{c}\text { Replace a conventional stove with } \\
\text { improved stove }\end{array}$ & $12 \%$ \\
\hline Buy an electrical heating device & $2 \%$ \\
\hline $\begin{array}{c}\text { Replace a heating device and improve the } \\
\text { ger's insulation performance }\end{array}$ & $8 \%$ \\
\hline Improve the ger's insulation performance & $19 \%$ \\
\hline $\begin{array}{c}\text { Desire improvement, but they are } \\
\text { financially impossible }\end{array}$ & $12 \%$ \\
\hline $\begin{array}{c}\text { Desires improvements but lacks a plan } \\
\text { Does not its necessity to make } \\
\text { improvements }\end{array}$ & $15 \%$ \\
\hline
\end{tabular}

According to Smith et al. ${ }^{55)}$, the average price of a baishin in Ulaanbaatar or an older one-room apartment on the urban fringe is approximately MNT 41,000,000, and an average monthly income above MNT 950,000 with a $30 \%$ down payment are required loan conditions. The median monthly income of the surveyed households was about MNT 600,000 , and only $16 \%$ of them met the loan conditions. Thus, for these households, leaving the ger districts seems unlikely, even for motivated households. About 114,000 households currently live in gers in Ulaanbaatar $^{3)}$, and they emit significant amounts of pollutants during the frigid winter months from their coalburning stoves, which are unavoidable heat sources for low-income households. It is vital to improve the thermal and environmental conditions of gers for urban settlers and replace the heating devices used by these families with better ones.

\section{Discussion}

As a countermeasure to air pollution, the Mongolian government started a pilot project that used excess overnight electricity in ger districts for heating to reduce emissions from coal-burning stoves ${ }^{56)}$ in January 2017. Between October and April, residents of the ger districts are able to use up to $700 \mathrm{kWh} / \mathrm{month}$ of electricity without cost from 22:00 p.m. until 6:00 a.m., and one-half of the cost of the electricity that exceeds that limit is subsidised.

Considering the fact that the heating capacity of popular improved stoves is about $6.5 \mathrm{~kW}^{25}$ ), a ger household using an improved stove for 12 hours per day would consume approximately 2.34 MWh per month, which costs about MNT 304,700 per month when electrical heating devices with an energy efficiency of 1.0 are used and the current subsidy is applied. In contrast, the average annual solid fuel cost in mid-2019 was MNT 741,412 according to a survey by UB stat ${ }^{57}$, which clearly suggests the economic advantage of coal stoves in running cost.

In fact, all the interviewees stated that they would be willing to use electrical heating systems instead of coalburning stoves if they could afford it. However, interviewees in five households explained that they had not applied to this electrical heater scheme because they did not have individual electrical meters; other interviewees stated that they did not have electrical heaters, so they did not qualify to participate in the pilot project.

Regarding the scenario of large-scale transition from coal stoves to electric heating, it is necessary to pay attention to not only the household financial abilities but also the regional power supply. Coal-power plants in Ulaanbaatar currently generate $0.9 \mathrm{GW}$ of electricity ${ }^{58)}$. If all 216,000 houses in the ger districts, including both gers and baishins, use electrical heaters, the power demand only for heat would at least be $1.2 \mathrm{GW}$, which exceeds the current capacity ${ }^{58)}$.

This fact implies that policies that encourage the switch from coal stoves to electric heating need to be implemented in conjunction with measures to reduce the thermal load, that is, to improve the insulation and airtightness of building envelopes. Chun-Kuen Tong et al. ${ }^{32)}$ pointed out that baishins in ger districts with low thermal insulating performance suffered from significant heat loss. In line with this research, the Mongolian central government and the World Bank implemented an insulation subsidy project for baishins ${ }^{59)}$. However, policies to improve the thermal performance of gers in the ger districts have not yet been implemented. Considering the large proportion of ger households in Ulaanbaatar, the pilot project to encourage the use of electrical heating in gers, which has already been initiated, should be redesigned to be coupled with activities to improve the thermal performance of ger envelopes.

In order to develop widely applicable methods for improving the thermal performance of gers, consideration should be given to the following ger-specific features. First, people disassemble and rebuild a ger almost every year, even if they do not relocate. This behaviour requires new insulation layers to be refastenable to either members or envelopes of the gers. In addition, in the case of sheetlike thermal insulating materials being applied as additional layers of envelopes, they should have sufficient 
strength to withstand tensile stress during assembly. Second, all components of the gers are currently well standardised and readily available to the public in markets. Therefore, it will be effective to standardise necessary members and parts for insulation and to encourage various companies to enter the manufacturing and sales business for the widespread use of the developed methods. The standardisation of the design of a windbreak room, which is ready-to-assemble and attached outside the entrance door, would also be effective for not only reducing the heat loss when opening or closing a door but also increasing the floor space. Third, the price of gers is extremely low, and people are fully accustomed to such monetary value. Gers are often more affordable than electric home appliances, such as a large LCD television. It is therefore highly unlikely for people to spend a large amount on improving the thermal performance of their gers, unless the effect of the measures is fully recognised. In other words, methods to improve insulation should be sufficiently inexpensive compared to the price of a ger. It is also indispensable to promote residents' understanding of improvement measures by transmitting xxappropriate information.

\section{Conclusion}

Considering the large contribution of coal stoves used in the ger districts to the current severe air pollution in Ulaanbaatar, prompt countermeasures for not only baishins but also gers are strongly needed. However, technology development and policy implementation for improving the thermal performance of ger envelopes have rarely been conducted. With this background, a field study on 49 gers in terms of structure and materials of gers, residents' lifestyles, and perceptions related to space heating were conducted in the ger districts of Ulaanbaatar in August 2018.

The results of the survey clearly show the excellence of gers in their affordability for low-income households owing to the highly standardised design, and access to local materials and manufacturing. Certainly, low cost has greatly contributed to providing small but relatively comfortable living spaces to migrants from rural to urban areas. On the other hand, the low costs of gers to which people have adapted to might create difficulties for increasing people's willingness to improve gers' thermal performance or replace coal stoves with more energy efficient and environmentally friendly heating devices, such as heat pumps tailored to cold climates. The present survey also suggests that most people have little knowledge about the quality and performance of ger envelopes. To remedy this situation, the development of affordable measures for improving ger envelopes and also wide public acknowledgement of the benefits based on scientific studies is necessary in the future.

\section{Acknowledgements}

All the study's activities were conducted in accordance with the requirements of research ethics regarding human subjects $^{60)}$. Part of this survey was financially supported by JSPS Grant-in-Aid for Scientific Research (C): 19K04730 and Sasakawa Scientific Research Grant from the Japan Science Society. We are grateful to all of the people who helped with this study: Associate Professor Munkhbayar B of the Mongolian University of Science and Technology, Mr. Tsogt-Od Ts, governor of the 18th khoroo, Sukhbaatar district, his office staff worker Ms. Oyunaa, and part-time staff of the office of the governor of the 17th khoroo, Bayangol district.

\section{Nomenclature}

Ger

Originally nomadic portable tents made of wooden poles covered with felted wool sheets.

Baishin Self-built detached house

Gerdistrict Residential area where have insufficient urban infrastructure for services such as water, sewage, garbage collection, and heating

$\begin{array}{ll}\text { khoroo } & \text { Micro-district } \\ \text { khoroolol } & \text { Equivalent for neighborhood } \\ \text { MNT } & \text { Official currency of Mongolia } \\ \text { esgii } & \text { Felt sheet } \\ \text { berzent } & \text { Tarpaulin } \\ \text { zulhai } & \text { Synthetic carded wool } \\ \text { toono } & \text { Skylight window } \\ \text { uni } & \text { pole } \\ \text { hana } & \text { wall } \\ \text { bagana } & \text { pillar } \\ \text { shal } & \text { Wood floor } \\ \text { hushig } & \text { Inner curtain for wall } \\ \text { haalga } & \text { door } \\ \text { busluur } & \text { Hoop rope } \\ \text { hayaawch } & \text { Lower edge of wall } \\ \text { urkh } & \text { Skylight window cover } \\ \text { deever } & \text { Roof cover } \\ \text { tuurga } & \text { Wall cover } \\ \text { clo } & \text { Clothing insulation value }\end{array}$

\section{References}

1) United Nations, "Sustainable Urban Development in Mongolia,” 2014.

2) World Meters, "Population of asia," (2019). https://www.worldometers.info/worldpopulation/asia-population/ (accessed May 8, 2019).

3) National Statistical Office of Mongolia, "Population and housing by census of Mongolia-National report year of 2015,” Ulaanbaatar, 2016. https://1212.mn/BookLibraryDownload.ashx?url=hu n_am_oron_suutsnii_2015_toollogo_eng.pdf\&ln=M $n$.

4) T. Byambadorj, M. Amati, and K.J. Ruming, "Twenty-first century nomadic city: ger districts and 
barriers to the implementation of the ulaanbaatar city master plan,” Asia Pac. Viewp., 52 (2) 165-177 (2011). doi:10.1111/j.1467-8373.2011.01448.x.

5) D. Maidar, and D. Darisuren, "Ger," Ulaanbaatar, 1976.

6) S. Omoya, "Housing life and consumer goods in recent mongolia-field survey,” pp.84-98 (1997). http://www.usp.ac.jp/user/usp/gakubu/jinbun/gakubu /gyouseki/bunka_03_1997.pdf (accessed May 9, 2019).

7) U. Kawagishi, H. Sugimoto, K. Kitano, G. Ishjamts, and N. Hirota, "Living environment of nomads residing on the outskirts of ulaanbaatar, mongolia part 2,” J. Asian Archit. Build. Eng., 9 (1) 139-146 (2018). doi:10.3130/jaabe.9.139.

8) S. Ochirbat, "Ger Area Redevelopment First Stage Location,” Ulaanbaatar, 2013.

9) H. Park, P. Fan, R. John, Z. Ouyang, and J. Chen, "Spatiotemporal changes of informal settlements: ger districts in ulaanbaatar, mongolia," Landsc. Urban Plan., $\quad 191 \quad 103630$

(2019). doi:10.1016/j.landurbplan.2019.103630.

10) H. Yatsuo, “Actual condition of detached houses and the way of living in the ger area , ulaanbaatar , mongolia,” Bull. Fac. Eng. Tokyo Polytech. Univ., 3 (1) 22-36 (2016). https://kougei.repo.nii.ac.jp/?action=pages_view_ma in\&active_action=repository_view_main_item_detai l\&item_id=1857\&item_no=1\&page_id=13\&block_i $\mathrm{d}=21$.

11) J. Caldieron, "Ger districts in ulaanbaatar, mongolia: housing and living condition surveys," Int. J. Innov. Appl. Stud., 4 (2) 465-476 (2013).

12) National Climatic Data Center, "Weather data of multiple cities,” (2017). www.ncdc.noaa.gov (accessed January 30, 2018).

13) UNICEF, “Mongolia’s Air Pollution Crisis: A call to action to protect children' s health," n.d. https://www.unicef.org/mongolia/Mongolia_air_poll ution_crisis_ENG.pdf.

14) World Health Organization, "Mongolia world health organization issues recommendations to tackle health impacts of air pollution in mongolia," (2018). http://www.wpro.who.int/mongolia/mediacentre/rele ases/20180228_recommendations_air_pollution/en/ \# (accessed December 24, 2018).

15) A.A. Soluyanov, D. Gresch, and M. Troyer, “Air pollution in Mongolia: policy brief,” 2016.

16) The World Bank, "CO2 emission," (2014). https://data.worldbank.org/indicator/EN.ATM.CO2E .$P C$ ?end $=2014 \&$ locations $=$ MN\&start $=1960$ (accessed September 5, 2019).

17) S. Dwiki, "Development of environmental policy in indonesia regarding mining industry in comparison with the united states and australia: the lesson that can be learned development of environmental policy in indonesia regarding mining industry in comparison with th," Evergr. Jt. J. Nov. Carbon Resour. Sci. Green Asia Strateg., 05 (2) 50-57 (2018). doi:10.5109/1936217.
18) T. Sato, "How is a sustainable society established? : a case study of cities in japan and germany," Evergr. Jt. J. Nov. Carbon Resour. Sci. Green Asia Strateg., 3 (2) 25-35 (2016). doi:10.5109/1800869.

19) T. Fujisaki, "Evaluation of green paradox: case study of japan,” Green Asia Educ. Cent. バージョン : published 権利関係: Evergr. Jt. J. Nov. Carbon Resour. Sci. Green Asia Strateg., 05 26-31 (2018). doi:10.5109/2174855.

20) United Nations, "Sustainable development goal 13," (2019). https://sustainabledevelopment.un.org/sdg13 (accessed September 6, 2019).

21) Law of Mongolia, “Law of land eviction,” (2015). https://www.legalinfo.mn/law/details/11219 (accessed July 17, 2019).

22) Japan International Cooperation Agency (JICA), C. and U. Ministry of Roads, Transportation, Development, and Ulaanbaatar City Government, "The Study on City Master Plan and Urban Development Program of Ulaanbaatar City (UBMPS),” Ulaanbaatar, 2009.

23) G. Enkhjargal, and N. Shigeo, "Study on environmental and social consideration in urban master plan of ulaanbaatar city,” Archit. Inst. Japan, 26 301-306 (2012).

24) T. Boldbaatar, K. Takami, and T. Fukui, "Estimation and present condition of 'ger' areas redevelopment project in ulaanbaatar,” Bull. Grad. Sch. Des. Eng. Hosei Univ., 6 (1-8) 378-403 (2017).

25) Ulaanbaatar Services Improvement Project, "Ulaanbaatar clean air project report," 2015.

26) Ulaanbaatar Electricity Distribution Network, "Ulaanbaatar electricity distribution network," (2019). http://tog.mn/public/show/id/10 (accessed February 19, 2019).

27) E. Otgonbayar, T. Matsumoto, and G. Khaltai, "Study on efficiency of air pollution control measures in ger area of ulaanbaatar in mongolia based on field survey," J. Japan Soc. Civ. Eng. Ser. G (Environmental Res., 69 (5) 259-265 (2013). https://www.jstage.jst.go.jp/article/jscejer/69/5/69_I _259/_article/-char/en.

28) P. Erdenedavaa, A. Adiyabat, A. Akisawa, and E. Otgonjanchiv, "Performance analysis of solar thermal system for heating of a detached house in harsh cold region of mongolia," Renew. Energy, 117 217-226

(2018). doi:10.1016/J.RENENE.2017.10.042.

29) A. Pillarisetti, M. Rongjiang, M. Buyan, N. Boldkhuu, A. Yuma, Y. Xudong, and S.R. Kirk, “Advanced household heat pumps for air pollution control: a pilot field study in ulaanbaatar, the coldest capital city in the world," Environ. Res., (2019). doi:10.1016/J.ENVRES.2019.03.019.

30) S. Ishikawa, H. Hayama, E. Purev-Erdene, M. Enai, K. Kikuta, and A. Kato, "Survey report for indoor environement of settled down type ger in ger area, Ulaanbaatar, Mongolia,” in: Summaries of Technical Papers of Annual Meeting, Hokkaido, 2007: pp. 5354. 
https://eprints.lib.hokudai.ac.jp/dspace/bitstream/211 5/50691/1/GKKD-2_53-54.pdf (accessed June 17, 2019).

31) B. Buyantogtokh, and Q. Zhang, "Investigation on indoor thermal environment of the gers in ulaanbaatar during winter (studies on indoor environment and energy consumption of dwelling in mongolia, part 2)," Environ. Eng. J. Archit. Institude Japan, 84 (757) 245-253 (2019).

32) J. Chun-Kuen Tong, T.M.-Y. Jason, and J.J. Phillip, "Development of thermal evaluation tool for detached houses in mongolia,” Energy Build., 173 81-90 (2018). doi:10.1016/j.enbuild.2018.05.026.

33) G. Ishjamts, A. Sukhbaatar, and S. Hirofumi, "Study on current situation of traditional dwelling in ulaanbaatar,” Miyakonojo Coll. Res. B., ISSN 0286 116 (2016).

34) J. Caldieron, and R. Miller, "Residential satisfaction in the informal neighborhoods of ulaanbaatar, mongolia,” Enq. A J. Archit. Res., 7 (1) 12-18 (2015). doi:10.17831/enq:arcc.v7i1.73.

35) Statistical Department of Ulaanbaatar, "Living condition of residents,” Ulaanbaatar, 2016. http://ubstat.mn/Upload/Reports/khun_amiin_amida rch_bui_orchin_nukhtsul_2016_ulaanbaatar_201706.pdf.

36) National Statistical Office of Mongolia, "Report of Employment 2017,” Ulaanbaatar, 2017. http://gemtel.mn/uploads/2017-onii-tandaltiintailan.pdf.

37) National Statistical Office of Mongolia, "Households socio economics statistics,” Ulaanbaatar, 2018. http://1212.mn/BookLibraryDownload.ashx?url=HS ES_tan_2018_2q.pdf\&ln=Mn.

38) National Statistical Office of Mongolia, "Housing, public service and amenities,” (2019). http://1212.mn/Stat.aspx?LIST_ID=976_L17\&type= description (accessed May 8, 2019).

39) Ministry of Construction and Urban Development, "Construction code for Developing design drawings for footing and foundation of building and facilities," Ulaanbaatar, Mongolia, 2016.

40) Mongolian Agency for Standartization and Metrology, "Mongolian national yurt mns 0370:2003,” (2003). http://www.estandard.gov.mn.

41) Mongolian Agency for Standardization and Meteology, "Insulation standars of mongolian ger mns 5801:2007,” 67 (6) 14-21 (2007).

42) A. Alexander, D. P Azevedo, Y. Hirako, and N. Tsering, "A manual of traditional Mongolian architecture,” Tibet Heritage Fund, 2006.

43) Mongolian Agency for Standads and Metrology, “Carded wool. mns 2481:2008," (2008).

44) Mongolian Agency for Standads and Metrology, “Esgii: pickled with needle mns 3283:1991,” (1991).

45) Mongolian Agency for Standads and Metrology, "Machine made wool felt. technical requirements. mns 0296:2012,” (2012).

46) Mongolian Agency for Standads and Metrology, "Textiles. covering wool felt. the test method.,"
(2008).

47) National Statistical Office of Mongolia, "Housing Price and Demand,” Ulaanbaatar, 2016. https://1212.mn.

48)Bulgan.B, "Washing machine user behavior research," University of Finance and Economics, 2016. http://repository.ufe.edu.mn/bitstream/handle/8524/5 56/Bulgan_Ugaalgaan machine hereglegchiin zan tuluv_PDF.pdf?sequence=1 (accessed March 4, 2019).

49) “Air pollution reduction department," (2018). http://aprd.ub.gov.mn/ (accessed February 18, 2019).

50) Asian Development Bank and Japan International Cooperation Agency, "Refined coal distribution project," Ulaanbaatar, 2018. http://aprd.ub.gov.mn/Media/Uploads/Tailan/ADB_ Report_SICA.pdf (accessed February 18, 2019).

51) National Department of Public Safety, "Safety publicity 2018-10-30,” (2018). https://nema.gov.mn/?p=42796 (accessed March 6, 2019).

52) S. Maruyama, and T. Mori, “Analysis on design method and energy consumption for high thermal performance housings," Japan Archit. Rev., 2 (4) 603-609 (2019). doi:10.1002/2475-8876.12112.

53) ASHRAE-55, “Ashrae standard 552010 thermal,” 137 (2010).

54) S. Schiavon, and K.H. Lee, "Dynamic predictive clothing insulation models based on outdoor air and indoor operative temperatures,” Build. Environ., 59 250-260 doi:10.1016/J.BUILDENV.2012.08.024.

(2013).

55) D. Smith, A. Founder, C. Anya, B. Raredon, M. Mcgowan, and A. Analyst, "Affordable housing Strategy for Ulaanbaatar,” 2014. http://www.usip.mn/uploads/reports/en/Affordable.p df (accessed April 3, 2019).

56) Ulaanbaatar Electricity Distribution Network, "Night time electrical subsidy| tog.mn,” (n.d.). http://www.tog.mn/public/newsshow/id/514 (accessed May 27, 2019).

57) Ulaanbaatar statistics, “Weekly report,” Ulaanbaatar, 2019. http://ubstat.mn/JobTables.aspx.

58) Ministry of Energy, "Ministry of energy,” (n.d.). http://energy.gov.mn/link/14 (accessed February 19, 2019).

59) Ulaanbaatar Services Improvement Project, "Ulaanbaatar Clean Air Project Third Quarter Report," 2018.

60) National Academy of Sciences, "A guide to responsible conduct in research (3rd ed.).,” 2009. https://www.nap.edu/books/12192/gif/R1.gif. 